\title{
PENINGKATAN KEMAMPUAN SOSIAL-EMOSIONAL SISWA KELOMPOK B MELALUI MEDIA BUKU CERITA KENABIAN: STUDI TINDAKAN KELAS PADA RAUDLATUL ATHFAL MUSLIMAT 10 MANYAR GRESIK
}

\author{
Nina Nuriyah Ma'arif \\ Sekolah Tinggi Agama Islam Daruttaqwa Gresik, Indonesia \\ Email: ninamaarif77@gmail.com \\ Maskanah \\ Guru RAM NU Banin Banat Manyar Gresik, Indonesia \\ Email: anamaskanah38@gmail.com
}

\begin{abstract}
This article discusses how to improve social-emotional abilities of early childhood through the medium of the storybooks about the prophets in Raudlatul Athfal Muslimat (RAM) 10 Manyar Gresik. This study used classroom action research (CAR). The techniques of data collection and analysis were carried out through a mixed-methods approach, namely quantitative and qualitative descriptive. In this regard, the data collection technique used observation, interviews, documents, and questionnaires. While the data analysis technique utilised descriptive statistics and qualitative analysis procedures such as categorising and interpreting the data found the ground, subsequently making conclusions. The study found that through the medium of the storybooks of the prophets' stories, the social-emotional ability of group B students have developed, namely in the first cycle, it increased to $76 \%$, ie 7 children developed suited to expectations and 6 children very well-developed. Whereas, in the second cycle, students' emotional social abilities increased to $86 \% ; 3$ children developed suited to expectations and 10 children very well-developed.
\end{abstract}

Keywords: Social-Emotional, Islamic Stories, Classroom Action, RAM NU Manyar.

\begin{abstract}
Abstrak: Artikel ini membahas perihal bagaimana meningkatkan kemampuan sosial-emosional pada anak usia dini melalui media buku cerita kisah-kisah nabi di Raudlatul Athfal Muslimat (RAM) 10 Manyar Gresik. Studi ini menggunakan penelitian tindakan kelas (PTK). Teknik pengumpulan dan analisis data dilakukan melalui pendekatan mixed-methods (metode gabungan), yakni kuantitatif deskriptif dan kualitatif. Untuk itu, itu teknik pengumpulan data menggunakan observasi, interview, dokumen, dan angket. Sedangkan teknik analisis data menggunakan statistik deskriptif dan penyusunan kategori, interpretasi data, dan penyimpulan. Studi menemukan bahwa melalui media buku cerita kisah-kisah nabi, kemampuan sosial-emosional iswa kelompok B di RAM 10 Manyar Gresik berkembang sesuai harapan dan sangat baik. Pada pada siklus I, meningkat menjadi $76 \%$, yakni 7 anak berkembang sesuai harapan dan 6 anak berkembang sangat baik. Pada siklus II, kemampuan sosial emosional mereka meningkat menjadi 86\% yakni 3 anak berkembang sesuai harapan, 10 anak berkembang sangat baik.
\end{abstract}

Kata Kunci: Sosial-Emosional, Cerita Islami, Tindakan Kelas, RAM NU Manyar. 


\section{Pendahuluan}

Dalam Undang-undang RI nomor 20 tahun 2003 tentang Sistem Pendidikan Nasional Bab 1 Ayat 14 menjelaskan bahwa pendidikan anak usia dini adalah suatu upaya pembinaan yang ditujukan kepada anak sejak lahir sampai usia 6 tahun yang dilakukan melalui pemberian rangsangan pendidikan untuk membantu partumbuhan dan perkembangan jasmani dan rohani agar anak memiliki kesiapan dalam memasuki pendidikan lebih lanjut. ${ }^{1}$

Anak usia dini adalah kelompok anak yang berada dalam proses pertumbuhan dan perkembangan yang bersifat unik, yakni memiliki pola pertumbuhan dan perkembangan motorik halus dan kasar, intelegensi, sosial emosional, bahasa dan komunikasi yang khusus sesuai dengan tingkat pertumbuhan dan perkembangan anak. ${ }^{2}$

Pada pasal 28 ayat 3 Sistem Pendidikan Nasional ditegaskan bahwa pendidikan anak usia dini jalur pendidikan formal berbentuk Taman Kanak-kanak (TK), Raudhatul Athfal (RA) atau bentuk lain yang sederajat. ${ }^{3}$ Dalam pandangan Islam, segala sesuatu yang dilaksanakan, tentulah memiliki dasar hukum baik itu yang berasal dari dasar naqliyah maupun dasar aqliyah. Begitu juga halnya dengan pelaksanaan pendidikan anak usia dini.

Hurlock menegaskan bahwa 5 tahun pertama kehidupan anak merupakan peletakan dasar bagi perkembangan masa selanjutnya. ${ }^{4}$ Anak yang terpenuhi segala kebutuhan fisik mapun psikis diawali perkembangan diperkirakan dapat melaksanakan tugas-tugas perkembangan pada tahap selanjutnya. Tidak hanya kemajuan dalam aspek bahasa, fisik, kognitif, nilai agama, dan moral, namun juga aspek emosi dan sosial.

Dengan demikian dapat kita pahami bahwa masa usia dini merupakan masa yang sangat menentukan dalam pembentukan karakter dan kepribadian seorang anak. Artinya usia itu, sebagai usia pengemban potensi intelegensi permanen dalam dirinya. Pengembangan potensi yang dimiliki anak, yang dianggap sangat penting dalam membantu meletakkan dasar kemampuan dan pembentukan sumber daya manusia yang berkualitas.

Dalam konteks perkembangan sosial emosional anak, Menurut Hurlock, perkembangan sosial emosional adalah perkembangan perilaku yang sesuai dengan tuntunan sosial, dimana perkembangan emosional adalah suatu proses dimana anak melatih rangsangan-rangsangan sosial terutama yang didapat dari tuntutan kelompok serta belajar bergaul dan bertingkah laku. ${ }^{5}$

Sedangkan menurut Salovey dan John Mayer yang dikutip dalam buku Ali Nugraha pengembangan sosial emosional meliputi: empati, mengungkapkan dan memahami perasaan, mengalokasi rasa marah, kemandirian, kemampuan menyesuaikan diri, disukai kemampuan menyelesaikan masalah antara pribadi, ketekunan, kesetiakawanan, kesopanan dan sikap hormat. ${ }^{6}$

Perkembangan sosial emosional tidak dapat dipisahkan satu sama lain. Dengan kata lain membahas perkembangan emosi harus bersinggungan dengan perkembangan sosial, begitu pula sebaliknya membahas perkembangan sosial harus melibatkan emosional, sebab keduanya terintegrasi dalam bingkai kejiwaan yang utuh. ${ }^{7}$

Ada banyak pihak yang dapat membantu perkembangan sosial emosional anak selain orang tua di rumah yaitu seorang guru di sekolah. Dalam rangka mengemban tugas dan tanggung jawab untuk mengoptimalkan perkembangan sosial emosional anak diperlukan suatu upaya yang dilakukan oleh guru agar perkembangan sosial emosional anak dapat berkembang secara optimal, upaya tersebut dapat dimulai dengan pemahaman guru melalui penerapan metode dalam proses pengembangan sosial emosional anak.

\footnotetext{
${ }^{1}$ Kemendiknas, Peraturan Menteri Nasional Republik. Indonesia Nomor 58 Tabun 2009 Tentang Standar Pendidikan Anak Usia Dini (Yogyakarta : bina insane mulia 2010), h. 3.

${ }^{2}$ Mansur, Pendidikan Anak Usia Dini Dalam Islam, Yogyakarta, Pustaka Belajar, 2005, h.88.

${ }^{3}$ Undang-Undang Sistem Pendidikan Nasional No. 20 Tahun 2003, h.19.

${ }^{4}$ Elizabeth B. Hurlock, Perkembangan Anak. ( Jakarta: Erlangga,tth), h. 20

${ }^{5}$ Elizabeth B Hurlock, Perkembangan Anak, ( Jakarta: Erlangga,tth), h. 26.

${ }^{6}$ Ali Nugraha, Metode Pengembangan Sosial Emosional, (Jakarta: Universitas Terbuka, 2011), h. 13

${ }^{7}$ Suyadi, Psikologi Belajar PAUD, (Yogyakarta:Bintang Pustaka Abadi, 2010), h. 109.
} 
Media buku cerita merupakan salah satu dari alat dalam proses pengembangan potensi natural anak. Ini karena cerita menawarkan kesempatan kepada anak untuk menginterprestasikan pengalaman langsung yang dialami anak. ${ }^{8}$ Dengannya, cerita tidak hanya berfungsi mengaktifkan aspek-aspek intelektual, tetapi juga aspek kepekaan, kehalusan budi emosi, seni, fantasi, dan imajinasi, yang tidak hanya mengutamakan otak kiri saja.

Anak usia dini harus dilatihkan untuk berani mengungkapkan yang dirasakan dan dipikirkan, sehingga pada nantinya anak dapat bekerjasama, dengan teman, mudah mengungkapkan pendapat di depan banyak orang dan mudah berinteraksi. Selain itu pentingnya sosial emosional anak yang baik, akan memperoleh keuntungan sosial pada berikutnya.

Dengan media buku cerita diharapkan peserta didik dapat mengembangkan kemampuan sosial emosional anak. Pendidikan di taman kanak-kanak perlu dikembangkan dan disesuaikan dengan kebutuhan dan perkembangan di segala bidang, baik dari segi sarana dan prasaranan pendidikan maupun kemampuan professional guna melaksanakan tugas mendidik dan mengajar.

Raudlatul Athfal Muslimat (RAM) 10 Manyar Gresik merupakan salah satu sekolah yang menyelenggarakan pendidikan anak usia dini yang menggunakan media buku cerita. Ia adalah salah satu alat yang digunakan guru dalam melaksanakan belajar mengajar di kelas sebagai upaya untuk mencapai tujuan pembelajaran yang telah ditetapkanll.

Dari sini, studi ini tertarik untuk membahas scara mendalam perihal upaya peningkatan kemampuan sosial-emosional anak kelompok B melalui media buku kisah-kisah nabi di Raudlatul Athfal Muslimat (RAM) 10 Manyar Gresik.

\section{Kajian Teoretik}

\section{Kemampuan Sosial Emosional Anak}

Perkembangan sosial adalah perkembangan prilaku anak dalam menyesuaikan diri dalam aturan-aturan masyarakat dimana anak itu berada. Sosialisasi merupakan suatu proses dimana individu terutama anak melatih kepekaan dirinya terhadap rangsangan-rangsangan social, terutama tekanan tekanan dan tuntutan-tuntutan kehidupan serta belcerita bergaul dengan bertingkah laku, seperti orang lain di dalam lingkungan sosialnya. ${ }^{9}$

Saat anak dilahirkan ke dunia mereka belum memiliki sifat sosial atau memiliki kemampuan untuk bergaul dengan orang lain. Perkembangan sosial anak sangat dipengaruhi oleh proses perlakuan dan bimbingan orang tua terhadap anaknya dalam mengenalkan berbagai aspek kehidupan sosial atau norma-norma tersebut dalam kehidupan sehari-hari.

Jadi, perkembangan sosial anak adalah kemampuan anak dalam merespon tingkah laku seseorang yang sesuai dengan norma-norma dan harapan sosial. Perkembangan sosial dinyatakan tidak oleh seorang saja, tetapi diperhatikan oleh orang-orang di kelompoknya. Objeknya adalah sosial dan dinyatakan berulang-ulang.

Sedangkan kecerdasan emosional yaitu kemampuan untuk mengendalikan, mengolah, dan mengontrol emosi agar mampu merespon secara positif setiap kondisi yang merangsang munculnya emosi-emosi ini. ${ }^{10}$

Dengan menarasikan cerita pada anak-anak, keterampilan emosi dan sosial mereka akan terlatih bagaimana mengatasi berbagai masalah yang timbul selama proses perkembangannya menuju manusia dewasa. Tidak hanya itu,dengan keterampilan emosi dan sosialnya, anak pun akan lebih mampu mengatasi tantangan-tantangan emosional dalam kehidupan modern.

Emosi merupakan suatu keadaan pada diri organisme ataupun individu pada suatu waktu tertentu yang diwarnai dengan adanya gradasi afektif mulai dari tingkatan yang lemah sampai pada tingkatan yang kuat (mendalam), seperti tidak teralu kecewa dan sangat kecewa.

\footnotetext{
8 Apriyanti Yofita Rahayu, Menumbubkan Kepercayaan Diri Melalui Kegiatan Bercerita, (Jakarta Barat: Indeks, 2013), h.80.

${ }^{9}$ Isjoni, Model Pembelceritaan Anak. Usia Dini, (Bandung: alfabeta. 2011). h. 30

${ }^{10}$ Riana Mashar, Emosi Anak Usia Dini dan Strategi Pengembangannya. Jakarta : Kencana Prenada Media Group, 2011. h. 60.
} 
Berbagai emosi dapat muncul dalam diri seperti sedih, gembira, kecewa, benci, cinta, marah. Sebutan yang diberikan pada emosi tersebut akan mempengaruhi bagaimana anak berfikir dan bertindak mengenai perasaan tersebut. ${ }^{11}$

\section{Memahami Media Buku Cerita Kisah-Kisah Nabi}

Buku adalah jendela dunia. Melalui buku, seseorang dipersilahkan masuk menatap dan menjelajah dunia yang sangat luas. Buku cerita dipahami sebagai alat pengajaran yang paling banyak digunakan di antara semua alat pengajaran lainnya. Buku cerita memberikan cerita dalam suatu bidang studi khususnya dalam keagamaan seorang anak didik.

Buku cerita merupakan segala bentuk buku yang digunakan untuk membantu guru atau instruktur dalam melaksanakan kegiatan belajar mengajar. Buku cerita dapat diartikan juga sebagai bahan-bahan atau materi pelajaran yang disusun secara lengkap dan sistematis berdasarkan prinsip-prinsip pembelajaran yang digunakan guru dan siswa dalam proses pembelajaran. ${ }^{12}$

Seperti terlihat dari namanya, buku cerita adalah jenis buku yang digunakan dalam aktivitas belajar dan mengajar. Prinsipnya semua buku dapat digunakan untuk bahan kajian pembelajaran. Namun, yang ingin disampaikan adalah pengertian buku cerita terkait dengan cara menyusun, penggunaannya dalam pembelajaran dan penyebarannya, sehingga buku tersebut termasuk kategori buku cerita.

Buku cerita disusun dengan alur dan logika sesuai dengan rencana pembelajaran. Buku cerita disusun sesuai kebutuhan belajar siswa. Buku cerita disusun untuk mencapai tujuan pembelajaran atau kompetensi tertentu.

Buku cerita atau materi pembelajaran (instructional materials) secara garis besar terdiri dari pengetahuan, keterampilan, dan sikap yang harus dipelajari anak didik dalam rangka mencapai standar kompetensi yang telah ditentukan. Secara terperinci, jenis-jenis materi pembelajaran terdiri dari pengetahuan (fakta, konsep, prinsip, prosedur), keterampilan, dan sikap atau nilai yang harus dipelajari anak didik dalam rangka mencapai standar kopetensi yang telah ditentukan. Buku atau materi kurikulum dapat bersumber dari berbagai disiplin ilmu baik yang berumpun ilmu-ilmu sosial (social science) maupun ilmu-ilmu alam (natural science). Selanjutnya yang perlu diperhatikan ialah bagaimana cakupan dan keluasan serta ke dalam materi atau isi dalam setiap bidang studi.

Buku cerita mempunyai kedudukan yang sangat penting dalam pendidikan, buku cerita juga mempunyai fungsi yang sangat strategis bagi proses pembelajaran yang dapat membantu guru dan siswa dalam kegiatan pembelajaran, sehingga guru tidak terlalu banyak menyajikan materi. Di samping itu, buku cerita dapat menggantikan sebagian peran guru dan mendukung pembelajaran individual. Hal ini akan memberikan dampak positif bagi guru, karena sebagian waktunya dapat dicurahkan untuk membimbing belajar siswa. Sehingga siswa mengurangi ketergantungan terhadap seorang guru dan membiasakan belajar secara mandiri, apabila suatu saat tanpa kehadiran seorang guru, siswa diharapkan tetap termotivasi dalam melakukan kegiatan belajar. ${ }^{13}$

Media buku cerita adalah media yang mampu menolong kemampuan sosial anak. Bercerita secara lisan mendukung anak-anak untuk belcerita membaca, memahami pengetahuan dunia, dan menjadikan sosial emosi baik.

Selain itu bercerita kisah-kisah Nabi juga merupakan kegiatan yang dilakukan seseorang secara lisan kepada orang lain dengan alat atau tanpa alat tentang apa yang harus disampaikan dalam bentuk pesan, informasi, atau dongeng untuk didengarkan dengan rasa yang menyenangkan. ${ }^{14}$

Media buku cerita kisah-kisah nabi adalah cara penyampaian atau penyajian materi pembelajaran secara lisan dalam bentuk cerita, khususnya kisah-kisah nabi dari guru kepada anak didik. Dalam pelaksanaan kegiatan pembelajaran di PAUD, media buku cerita kisah-kisah nabi dilaksanakan dalam upaya memperkenalkan, memberikan keterangan, atau penjelasan tentang hal baru dalam rangka menyampaikan pembelajaran yang dapat mengembangkan berbagai

\footnotetext{
11 Yudrik Jahja, Psikologi Perkembangan, (Jakarta : Kencana, 2012), h. 136.

12 Depdiknas, 2008

${ }^{13}$ Depdiknas, 2007

${ }^{14}$ Apriyanti Yofita Rahayu, Menumbubkan Kepercayaan Diri Melalui Kegiatan Bercerita, (Jakarta: Indeks, 2013), h. 80.
} 
kompetensi dasar usia anak, sehingga dapat menjadi tauladan dan dapat mengembangkan moral serta keagamaan seorang anak didik. ${ }^{15}$

Berdasarkan uraian tersebut dapat disimpulkan bahwa fungsi media buku cerita kisah-kisah nabi adalah dapat memperjelas penyajian pesan dan informasi, meningkatkan dan mengarahkan perhatian anak, mengatasi keterbatasan indera, ruang, dan waktu, memberikan kesamaan pengalaman kepada siswa tentang peristiwa-peristiwa di lingkungan mereka, serta memungkinkan terjadinya interaksi langsung dengan guru, masyarakat, dan lingkungannya.

\section{Metode Penelitian}

Jenis penelitian ini adalah penelitian tindakan kelas (PTK). Dalam pendekatan PTK, peneliti melakukan dua siklus. Di setiap siklus melewati empat tahapan, yakni perencanaan, pelaksanaan, pengamatan, dan refleksi sebagai berikut:

1. Rancangan penelitian

Adapun tahap-tahap dalam rancangan penelitian ini adalah :

a. Tahap perencanaan tindakan.

b. Tahap pelaksanaan tindakan.

c. Tahap observasi

d. Tahap refleksi

e. Tahap revisi

Subyek penelitian ini adalah para guru dan siswa kelompok B RAM NU 10 Banin Banat (lakiperempuan) Manyar Gresik. Jumlah siswa kelompok B berjumlah 32 anak, yang terdiri dari 13 siswa laki-laki dan 19 siswa perempuan. Untuk lebih mudah mengenai sumber data, bisa dilihat pada tabel 1.

Tabel 1 'Informan penelitian'

\begin{tabular}{|l|l|l|}
\hline \multicolumn{1}{|c|}{ Data } & \multicolumn{1}{|c|}{ Metode } & \multicolumn{1}{c|}{ Informan \& responden } \\
\hline $\begin{array}{l}\text { Kemampuan sosial } \\
\text { emosional pada anak }\end{array}$ & $\begin{array}{l}\text { Wawancara, kuesioner, } \\
\text { observasi, dokumentasi }\end{array}$ & $\begin{array}{l}\text { Kepala sekolah, wakil kepala sekolah, } \\
\text { waka kurikulum, komite sekolah, Orang } \\
\text { Tua siswa. }\end{array}$ \\
\hline $\begin{array}{l}\text { Penerapan kemampuan } \\
\text { sosial emosional anak } \\
\text { melalui media buku cerita } \\
\text { kisah-kisah Nabi }\end{array}$ & $\begin{array}{l}\text { Wawancara, kuesioner, } \\
\text { Observasi, Dokumentasi }\end{array}$ & $\begin{array}{l}\text { Kepala sekolah, wakil kepala sekolah, } \\
\text { komite sekolah, koordinator TU, waka } \\
\text { kurikulum, guru dan Orang Tua siswa. }\end{array}$ \\
\hline
\end{tabular}

Adapun dalam pengumpulan data, studi ini melakukan beberapa teknik, antara lain, pertama angket atau kuisioner. William J. Goode dan Paul K. Hatt mengatakan bahwa questionaire refers to a defice for securing answer to question by using a form which the responden fills in bim self. ${ }^{16}$ Kuisioner menunjuk pada sejumlah pertayaan tertulis yang di gunakan untuk memperoleh informasi dari responden dalam arti laporan pribadinya atau hal-hal yang ia ketahui.

Instrumen kuisioner ini penulis gunakan untuk mengumpulkan data tentang kemampuan sosial emosional pada anak, karena variabel tersebut tidak dapat diamati secara langsung, maka pengukuran dilakukan dengan secara tidak langsung melalui self report. Instrumen kuisioner tersebut disusun dan dikembangkan sendiri oleh penulis dengan membuat sejumlah pernyataan yang berkaitan dengan kemampuan sosial emosional pada anak.

Pernyataan tentang kemampuan sosial emosional pada anak tersebut berjumlah 10 item, yang masing-masing item diikuti oleh 4 alternatif jawaban yang menunjukkan pernyataan sikap pada suatu kontinum psikologis yang akan menunjukkan derajat, favorabel atau tak favorabelnya pernyataan yang bersangkutan.

Sesuai dengan masalah dan tujuan yang penulis rumuskan, maka pertanyaan interview diklasifikasi menjadi tiga bagian, yaitu :

${ }^{15}$ Nurbiana dkk, Metode Pengembangan Bahasa, Universitas Terbuka. h. 66.

${ }^{16}$ Goode William J., and Paul, K., 1981, Methods in Social Research, (MC Graw Hill Book Company, Singapore.) hal. 133 
a. Poin $1-5$ tentang kemampuan sosial emosional anak usia dini di RAM 10 Manyar Gresik.

b. Poin 6-10 tentang penerapan kemampuan sosial emosional anak kelompok B melalui media buku cerita kisah-kisah Nabi di RAM 10 Manyar Gresik.

Adapun data yang diperoleh dari penyebaran angket ini masing-masing diberi 3 alternatif jawaban, kemudian dinilai dengan cara menjumlah dari setiap jawaban orang tua. Sebagai standart penulis tetapkan sebagai berikut :

a. Alternatif "a" diberi skor 3 dengan kategori baik

b. Alternatif "b" diberi skor 3 dengan kategori cukup

c. Alternatif "c" diberi skor 3 dengan kategori kurang

Kedua, dokumentasi. Di samping instrument instrumen kuisioner, penulis juga menggunakan dokumentasi (Suharsimi Arikunto mengatakan bahwa dokumentasi merupakan barang-barang tertulis yang diperlukan peneliti untuk memperlancar penelitian). Dokumentasi ini digunakan oleh peneliti untuk memperoleh data-data yang diperlukan penelitian seperti keadaan anak didik, jumlah anak didik seluruhnya, dan lain sebagainya. ${ }^{17}$ Ketiga, observasi. Metode ini penulis gunakan untuk memperoleh keterangan tentang keadaan yang berhubungan dengan letak geografis, struktur organisasi sekolah dan daya lain yang diperlukan. Keempat adalah interview. Teknik ini dilakukan secara tatap muka ${ }^{18}$ yang digunakan untuk mengumpulkan data tentang sejarah atau latar belakang berdirinya lembaga serta hal-hal yang kurang jelas dari jawaban angket, sehingga perlu ditanyakan kembali kepada gurunya sebagai pembimbing secara langsung.

Sedangkan teknik analisis data yang digunakan dalam studi ini adalah statistik deskriptif dan analisis kualitatif deskriptif. Statistik deskriptif digunakan untuk menganalisis frekwensi dan persentasi jawaban rumusan masalah pertama dan kedua, yakni hasil penerapan kemampuan sosial emosional anak kelompok B melalui media buku cerita kisah-kisah nabi di RAM 10 Manyar Gresik. Berikut rumus stattisktik yang digunakan:

$$
\mathrm{P}=\frac{\mathrm{F}}{\mathrm{N}} \times 100 \%
$$

Keterangan :

$$
\begin{array}{ll}
\mathrm{P} & =\text { Populasi } \\
\mathrm{F} & =\text { Frekuensi Jawaban Responden } \\
\mathrm{N} & =\text { Jumlah Responden } \\
100 \% & =\text { Bilangan Standarisasi }
\end{array}
$$

Untuk teknik analisa kualitatif, peneliti akan mengatur urutan data, mengorganisasikannya kedalam suatu pola, kategori dan suatu uraian dasar. Proses ini dimaksudkan untuk menemukan tema dan dirumuskannya hipotesis kerja seperti yang disarankan oleh data yang akhirnya dapat diangkat menjadi teori subtantif. ${ }^{19}$

Data-data yang diperoleh dari kepustakaan secara kualitatif dengan tahapan-tahapan editing, pengorganisasian data, dan analisis lanjtan. Editing adalah memeriksa kembali semua yang diperoleh terutama dari segi kelengkapan, keterbacaan, kejalasan makna, kesesuaian dan keselarasan satu dengan yang lainnya, relevansi dan karagaman satuan/ kelompok data.

Sedangkan pengorganisasian data yaitu menyusun dan mensistematiskan data-data yang diperoleh kedalam kerangka paparan yang direncanakan. Tahap terakhir dilakukan analisis lanjutan terhadap hasil pengorganisasian data dengan menggunakan kaidah, teori, dan sebagainya yang berkenaan dengan pembahasan.

\footnotetext{
17 Arikunto, Suharsimi, 1996, Prosedur Penelitian suatu Pendekatan Praktek, (Rineka Cipta, Jakarta). hal. 149

18 Sanapiah Faisal, Metodologi Penelitian Pendidikan, ( Surabaya: Usaha Nasional, 1989), hal. 213

${ }^{19}$ Lexy J Moloeng, Metodologi Penelitian Kualitatif, (Remaja Rosdakarya, Bandung), hal.103.
} 


\section{Hasil Penelitian dan Pembahasan \\ Deskripsi Demografis}

RAM NU 10 Banin Banat Manyar Gresik terletak di jalan Ky. Sahlan XI/15 Sidomukti kecamatan Manyar kabupaten Gresik, yang berdiri pada tahun 1971. RAM NU 10 Banin Banat Manyar di bangun diatas tanah hak milik sendiri dengan luas 600 M. Sekolah dibangun dengan sarana dan prasarana yang cukup memadai serta berada pada lingkungan masyarakat yang sangat kondusif untuk melaksanakan PBM. Berdasarkan sejarah, berawal dari pengamatan sebagian tokoh masyarakat dan tenaga pendidik yang ada di kecamatan manyar, bahwa sekolah RA ini didirikan karena anjuran pemerintah dan usulan tokoh masyarakat agar murid mengikuti sekolah formal sebelum mereka melanjutkan ke jenjang pendidikan sekolah dasar, sehingga akhirnya didirikanlah RAM NU 10 Banin Banat Manyar.

RAM NU 10 Banin Banat Manyar memandang bahwa pendidikan yang paling mendasar untuk menjadi manusia yang sehat jasmani dan rohani yaitu dengan memberikan pendidikan yang tepat sejak kecil yang seimbang antara intelektulitas dengan pendidikan rohani.

Tabel 2 'Daftar nama guru RAM NU 10 banin banat Manyar'

\begin{tabular}{|c|l|l|l|}
\hline No & \multicolumn{1}{|c|}{ Nama } & \multicolumn{1}{c|}{ Tempat Tg1 Lahir } & \multicolumn{1}{c|}{ Jabatan } \\
\hline 1 & Mumayyirotul Fitriyah,S.Pdi & Gresik,27-07-1974 & Kepala \\
\hline 2 & Nur Hani'ah ,S.Pdi & Gresik,19-07-1967 & Wakil \\
\hline 3 & Hidayatul Annisak, S.Pd & Gresik,26-03-1970 & Guru Kelas \\
\hline 4 & Chuzaimah,S.Pd & Gresik,03-03-1960 & Guru Kelas \\
\hline 5 & Rohmatul Uyun,S.Pd & Gresik,17-10-1968 & Guru Kelas \\
\hline 6 & Istamhidah & Jakarta, 08-11-1971 & Guru Kelas \\
\hline 7 & Azimatul Chusnah ,S.Pd & Gresik,24-07-1973 & Guru Kelas \\
\hline 8 & Mariya Ulfah ,S.Pd & Gresik,16-09-1976 & Guru Kelas \\
\hline 9 & Muthmainnah,S.Pd & Gresik,26-03-1977 & Guru Kelas \\
\hline 10 & N. Hamidah S.Pd & Gresik,31-07-1979 & Guru Kelas \\
\hline 11 & Wardatul Choiriyah,S.Pdi & Gresik,09-02-1973 & Guru Kelas \\
\hline 12 & Hidayatul Mu'minah ,S.Pd & Gresik,24-03-1983 & Guru Kelas \\
\hline 13 & Wiwik Muthowi'ah,M.Pdi & Mojokerto,16-06-1965 & Guru Kelas \\
\hline 14 & Ilmiyatis Salamah,S.Pd & Gresik,02-03-1984 & Guru Kelas \\
\hline 15 & Chalimatus Sa'diyah,S.Pd & Gresik,24-09-1984 & Guru Kelas \\
\hline 16 & Siti Zahroh ,S.Pdi & Gresik,04-07-1980 & Guru Kelas \\
\hline 17 & Durrotun Nafisah, S.Pdi & Gresik,09-02-1981 & Guru Kelas \\
\hline 18 & Dyah Pramestiningsih,Spt & Banjar Baru, 19-08-1971 & Tenaga Kependidikan \\
\hline 19 & Uswatul Karimah, Se. & Gresik, 27-01-1990 & Tenaga Kependidikan \\
\hline 20 & Siti Khodijah, S.Pd & Gresik, 05-10-1992 & Tenaga Kependidikan \\
\hline 21 & Miftahur Rohmad & Gresik,07-06-1975 & Tenaga Kependidikan \\
\hline 22 & Maskanah & Gresik,26-03-1983 & Tenaga Kependidikan \\
\hline
\end{tabular}

Siswa RAM NU 10 Banin Banat Manyar Gresik pada tahun 2017/2018 berjumlah 32 anak dengan laki-laki 18 dan perempuan 14 sebagai berikut :

Tabel 3 'Data siswa RAM NU 10 banin banat Manyar tahun 2017/2018'

\begin{tabular}{|c|l|c|c|c|}
\hline No & \multicolumn{1}{|c|}{ Nama Siswa } & Tempat Lahir & Tgl.Lahir & Kelompok \\
\hline 1 & Ahmad Zainuri & Gresik & $25 / 08 / 2012$ & B \\
\hline 2 & Aisya Nur Azizah & Gresik & $23 / 06 / 2012$ & B \\
\hline 3 & Aqila Salma Nafisah Arif & Gresik & $24 / 04 / 2012$ & B \\
\hline 4 & Azila Salma Nafisah Arif & Gresik & $24 / 04 / 2012$ & B \\
\hline 5 & Dwi Fadilatuz Zahra & Gresik & $19 / 03 / 2012$ & B \\
\hline 6 & Kaila Putri & Gresik & $27 / 03 / 2012$ & B \\
\hline 7 & Kevin Sulthoni & Gresik & $11 / 04 / 2012$ & B \\
\hline 8 & Muhammad Zidan & Gresik & $19 / 10 / 2012$ & B \\
\hline
\end{tabular}




\begin{tabular}{|c|l|l|l|l|}
\hline 9 & M. Alvan Maulana & Gresik & $29 / 12 / 2012$ & B \\
\hline 10 & Muhammad Reza & Gresik & $12 / 04 / 2012$ & B \\
\hline 11 & Muhammad Rico Saputra & Gresik & $26 / 03 / 2012$ & B \\
\hline 12 & Zain Ashari Amrullah & Gresik & $05 / 10 / 2012$ & B \\
\hline 13 & Adrian Faiz Prasetya & Gresik & $14 / 01 / 2011$ & B \\
\hline 14 & Aida Haresti Zahra & Gresik & $30 / 03 / 2012$ & B \\
\hline 15 & Amabel Damara Elyfia & Gresik & $23 / 05 / 2011$ & B \\
\hline 16 & Arumi Warnasita & Gresik & $20 / 07 / 2011$ & B \\
\hline 17 & Imam Ikhwanul Kirom & Gresik & $16 / 09 / 2011$ & B \\
\hline 18 & Jaka Maulana Firmansyah & Gresik & $19 / 06 / 2011$ & B \\
\hline 19 & Marizka Oktaviani & Gresik & $19 / 09 / 2011$ & B \\
\hline 20 & Miftahul Sofiya Hartanti & Gresik & $24 / 11 / 2011$ & B \\
\hline 21 & Muhammad Ainun Majid & Gresik & $28 / 01 / 2011$ & B \\
\hline 22 & Muhammad Ali Fahmi & Gresik & $27 / 02 / 2011$ & B \\
\hline 23 & Muhammad Fahri Listian & Gresik & $09 / 11 / 2011$ & B \\
\hline 24 & Muhammad Rendi & Gresik & $20 / 10 / 2011$ & B \\
\hline 25 & Muhammad Rohid & Gresik & $21 / 02 / 2011$ & B \\
\hline 26 & Muhammad Surya & Gresik & $05 / 05 / 2011$ & B \\
\hline 27 & Niam Zulkarnain & Gresik & $06 / 11 / 2011$ & B \\
\hline 28 & Reyhan Efendi & Gresik & $20 / 06 / 2011$ & B \\
\hline 29 & Risa Dafiyah Abidah & Gresik & $14 / 01 / 2011$ & B \\
\hline 30 & Vita Velysa Aura Salwa & Gresik & $06 / 04 / 2011$ & B \\
\hline 31 & Weny Winda Yanti & Gresik & $27 / 06 / 2011$ & B \\
\hline 32 & Zul Zeti Romatia & Gresik & $01 / 03 / 2011$ & B \\
\hline
\end{tabular}

\section{Analisis Data Kualitatif}

Berdasarkan dari hasil pengumpulan data yang sudah dilakukan bahwa hasil penelitian ini sesuai dengan tujuan penelitian yang dikemukakan pada bab I. Pada siklus I yaitu bulan Mei dan siklus II bulan Juni 2018. Adapun hasil pengumpulan data pada siklus I dan II dideskripsikan sebagai berikut:

\section{Siklus I}

a. Tahap perencanaan

Pada tahap ini peneliti mempersiapkan tes lisan untuk mengetahui kemampuan sosial emosional pada anak kelompok B melalui media buku cerita kisah-kisah Nabi di RAM 10 Manyar Gresik.

b. Tahap pelaksanaan tindakan

Pelaksanaan kegiatan belajar mengajar untuk siklus I dilaksanakan pada bulan Mei di kelompok B RAM NU 10 Banin Banat Manyar Gresik dengan jumlah siswa 20. Dalam hal ini peneliti bertindak sebagai guru.

Pada akhir pembelajaran siswa diberi tes lisan dengan tujuan mengetahui tingkat keberhasilan siswa dalam pembelajaran yang telah dilakukan. Adapun data hasil penelitian pada siklus I adalah sebagai berikut:

\section{Tabel 4}

'Data distribusi nilai (skor) tes kemampuan sosial emosional pada anak kelompok B melalui media buku cerita kisah-kisah nabi di RAM 10 Manyar Gresik siklus I'

\begin{tabular}{|c|l|c|c|c|c|}
\hline \multirow{2}{*}{ No } & \multicolumn{1}{|c|}{ Nama Siswa } & \multicolumn{5}{c|}{ Kriteria } \\
\cline { 3 - 6 } & \multicolumn{1}{|c|}{4} & 3 & 2 & 1 \\
\hline 1 & Adrian Faiz Prasetya & & $\sqrt{ }$ & & \\
\hline 2 & Aida Haresti Zahra & $\sqrt{ }$ & & & \\
\hline 3 & Amabel Damara Elyfia & $\sqrt{ }$ & & $\sqrt{ }$ & \\
\hline 4 & Arumi Warnasita & $\sqrt{ }$ & & & \\
\hline 5 & Imam Ikhwanul Kirom & & & \\
\hline
\end{tabular}




\begin{tabular}{|c|l|r|r|r|c|}
\hline 6 & Jaka Maulana Firmansyah & & $\sqrt{ }$ & & \\
\hline 7 & Marizka Oktaviani & & $\sqrt{ }$ & & \\
\hline 8 & Miftahul Sofiya Hartanti & $\sqrt{ }$ & & & \\
\hline 9 & Muhammad Ainun Majid & & $\sqrt{ }$ & & \\
\hline 10 & Muhammad Ali Fahmi & & & $\sqrt{ }$ & \\
\hline 11 & Muhammad Fahri Listian & & & $\sqrt{ }$ & \\
\hline 12 & Muhammad Rendi & & & & $\sqrt{ }$ \\
\hline 13 & Muhammad Rohid & & & $\sqrt{ }$ & \\
\hline 14 & Muhammad Surya & & & $\sqrt{ }$ & \\
\hline 15 & Ni'am Zulkarnain & & & $\sqrt{ }$ & \\
\hline 16 & Reyhan Efendi & & $\sqrt{ }$ & & \\
\hline 17 & Risa Dafiyah Abidah & $\sqrt{ }$ & & & \\
\hline 18 & Vita Velysa Aura Salwa & & & & $\sqrt{ }$ \\
\hline 19 & Weny Winda Yanti & & & & \\
\hline 20 & Zul Zeti Romatia & & & & \\
\hline
\end{tabular}

Keterangan :
$4=$ Bisa menjawab 1-5 pertanyaan dengan benar
$3=$ Bisa menjawab 1-3 pertanyaan dengan benar
$2=$ Hanya bisa menjawab 1 pertanyaan dengan benar
$1=$ Belum bisa menjawab pertanyaan dengan benar

Berdasarkan hasil penelitian siklus I peningkatan kemampuan sosial emosional anak kelompok B melalui media buku cerita kisah-kisah Nabi di RAM 10 Manyar Gresik, 5 anak masuk kriteria sangat baik, 7 anak baik, 6 anak cukup baik, dan 2 anak kurang baik.

Untuk itu diperlukan perbaikan pada siklus I, sebagai usaha untuk memperbaiki hasil belajar siswa. Oleh karena itu, di dalam siklus berikutnya berharap agar peningkatan kemampuan sosial emosional anak kelompok B melalui media buku cerita kisah-kisah Nabi lebih maksimal lagi.

\section{Tabel 5}

'Data ketuntasan hasil belajar siswa tentang peningkatan kemampuan sosial emosional anak kelompok B melalui media buku cerita kisah-kisah nabi siklus I'

\begin{tabular}{|c|l|c|l|}
\hline No & \multicolumn{1}{|c|}{ Nama Siswa } & Bintang & \multicolumn{1}{|c|}{ Kriteria } \\
\hline 1 & Ahmad MaulanaHaqiqi & 3 & Berkembang sesuai harapan \\
\hline 2 & Ahkmad Raza Natagara & 3 & Berkembang sesuai harapan \\
\hline 3 & Bela Kurniawati & 2 & Mulai berkembang \\
\hline 4 & Dhea Shafiratuz Zahroh & 1 & Belum berkembang \\
\hline 5 & FaizatinNisa' & 3 & Berkembang sesuai harapan \\
\hline 6 & Friska Cecilia & 2 & Mulai berkembang \\
\hline 7 & Habibatul Azifah & 2 & Mulai berkembang \\
\hline 8 & Muhammad Asrori & 1 & Belum berkembang \\
\hline 9 & M. AzamUbaidillah & 1 & Belum berkembang \\
\hline 10 & M. Fakhry Ali Rabbani & 2 & Mulai berkembang \\
\hline 11 & Muhammad Fakry Listian & 3 & Berkembang sesuai harapan \\
\hline 12 & M. Fatkhur Nur Rohman & 1 & Belum berkembangl \\
\hline 13 & M. Refan Hibatullah & 3 & Berkembang sesuaiharapan \\
\hline 14 & Tsania Alifatur Rahmah & 2 & Mulai berkembang \\
\hline 15 & Ni'am Zulkarnain & 2 & Mulai berkembang \\
\hline 16 & Reyhan Efendi & 1 & Belum berkembang \\
\hline 17 & Risa Dafiyah Abidah & 1 & Belum berkembang \\
\hline 18 & Vita Velysa Aura Salwa & 1 & Belum berkembang \\
\hline 19 & Weny Winda Yanti & 2 & Mulai berkembang \\
\hline 20 & Zul Zeti Romatia & & \\
\hline
\end{tabular}


Berdasarkan hasil penelitian pada siklus I kemampuan sosial emosional anak kelompok B melalui media buku cerita kisah-kisah Nabi di RAM 10 Manyar Gresik, 8 anak masuk kriteria belum berkembang, 6 anak masuk kriteria mulai berkembang dan 5 anak berkembang sesuai harapan.

Untuk itu diperlukan perbaikan pada siklus I, sebagai usaha untuk memperbaiki hasil belajar siswa. Oleh karena itu, di dalam siklus berikutnya berharap agar peningkatan kemampuan sosial emosional anak kelompok B melalui media buku cerita kisah-kisah Nabi di RAM 10 Manyar Gresik lebih maksimal lagi.

c. Tahap observasi

Tahap ini dilaksanakan bersamaan dengan pelaksanaan tindakan, dari hasil pengamatan yang dilakukan peneliti dan dibantu oleh teman sejawat maka diperoleh hasil sebagai berikut:

\section{Tabel 6}

'Pedoman observasi tentang peningkatan Kemampuan Sosial Emosional Anak Kelompok B Melalui Media Buku Cerita Kisah-Kisah Nabi pada siklus I'

\begin{tabular}{|c|l|c|}
\hline No & \multicolumn{1}{|c|}{ Aktivitas belajar siswa } & Criteria \\
\hline 1 & Memperhatikan penjelasan guru & 3 \\
\hline 2 & Siswa berperan aktif dalam pembelajaran & 2 \\
\hline 3 & Tanggap dengan media pembelajarn yang telah diterapkan oleh guru & 3 \\
\hline 4 & Berprilaku yang sesuai selama KBM berlangsung & 3 \\
\hline 5 & Selalu mengikuti kegiatan-kegiatan di sekolah & 2 \\
\hline
\end{tabular}

Keterangan :

$$
\begin{array}{ll}
1 & =\text { Tidak positif } \\
2 & =\text { Cukup positif } \\
3 & =\text { Positif } \\
4 & =\text { Sangat positif }
\end{array}
$$

\section{Tabel 7}

'Data aktivitas belajar siswa tentang peningkatan Kemampuan Sosial Emosional Anak Kelompok B Melalui Media Buku Cerita Kisah-Kisah Nabi siklus I'

\begin{tabular}{|c|l|c|}
\hline No & \multicolumn{1}{|c|}{ Nama Siswa } & Kriteria \\
\hline 1 & Ahmad MaulanaHaqiqi & 3 \\
\hline 2 & Ahkmad Raza Natagara & 3 \\
\hline 3 & Bela Kurniawati & 3 \\
\hline 4 & Dhea Shafiratuz Zahroh & 3 \\
\hline 5 & FaizatinNisa & 2 \\
\hline 6 & Friska Cecilia & 2 \\
\hline 7 & Habibatul Azifah & 1 \\
\hline 8 & Muhammad Asrori & 2 \\
\hline 9 & M. AzamUbaidillah & 2 \\
\hline 10 & M. Fakhry Ali Rabbani & 1 \\
\hline 11 & Muhammad Fakry Listian & 3 \\
\hline 12 & M. Fatkhur Nur Rohman & 2 \\
\hline 13 & M. Refan Hibatullah & 3 \\
\hline 14 & Tsania Alifatur Rahmah & 2 \\
\hline 15 & Ni’am Zulkarnain & 2 \\
\hline 16 & Reyhan Efendi & 1 \\
\hline 17 & Risa Dafiyah Abidah & 3 \\
\hline 18 & Vita Velysa Aura Salwa & 2 \\
\hline 19 & Weny Winda Yanti & 3 \\
\hline 20 & Zul Zeti Romatia & \\
\hline
\end{tabular}


Menurut data diatas bahwa secara garis besar aktivitas siswa yaitu dalam kriteria tidak positif 3 anak, cukup positif 9 anak dan positif 8 anak.

\section{Tabel 8}

'Data aktivitas guru yang dinilai teman sejawat tentang peningkatan Kemampuan Sosial Emosional Anak Kelompok B Melalui Media Buku Cerita Kisah-Kisah Nabi siklus I'

\begin{tabular}{|c|l|c|}
\hline No & \multicolumn{1}{|c|}{ Aktivitas guru } & skor \\
\hline 3 & $\begin{array}{l}\text { Membimbing siswa dalam meningkatkan kemampuan sosial emosional } \\
\text { anak kelompok B melalui media buku cerita kisah-kisah Nabi }\end{array}$ & 3 \\
\hline 4 & Menggunakan media dan sumber yang beragam & 3 \\
\hline 5 & Memberikan tantangan kepada siswa dengan memberikan penghargaan & 2 \\
\hline 6 & Menguasai kelas & 2 \\
\hline 7 & Proses pembelajaran sesuai RPPH & 3 \\
\hline
\end{tabular}

Keterangan nilai skor:

$1=$ Kurang baik3 = Baik

$2=$ Cukup baik $4=$ Baik sekali

Menurut data diatas bahwa secara garis besar aktivitas guru rata-rata 3 yaitu dalam kategori baik akan tetapi masih terdapat kekurangan diantaranya guru tidak memberikan tantangan kepada siswa dengan memberikan penghargaan.

d. Refleksi dalam pelaksanaan kegiatan belajar mengajar yang di peroleh informasi dari hasil pengamatan sebagai berikut :

1. Hanya beberapa siswa yang termotivasi

2. Keterlibatan siswa dalam kbm belum merata

3. Guru kurang bisa mengelola waktu

e. Revisi

Pelaksanaan kegiatan belajar mengajar pada siklus I ini masih terdapat siswa yang belum berkembang dalam aspek peningkatan kemampuan sosial emosional anak kelompok B melalui media buku cerita kisah-kisah Nabi, sehingga perlu adanya revisi untuk di lakukan pada siklus berikutnya antara lain :

1) Guru dalam memotifasi siswa hendaknya memberikan tantangan dan harapan siswa untuk mencapainya.

2) Guru harus lebih dekat dengan siswa sehingga tidak perasaaan takut dalam diri siswa baik untuk mengemukakan pendapat atau bertanya.

3) Guru harus lebih sabar dalam membimbing siswa.

4) Guru harus mendistribusikan waktu secara baik sehingga kegiatan pembelajaran dapat berjalan sesuai harapan.

5) Guru harus bisa menguasai kelas agar agar proses pembelajaran bisa optimal.

\section{Siklus II}

a. Tahap perencanaan

Pada tahap ini peneliti mempersiapkan perangkat pembelajaran dan soal tes lisan, serta media yang mendukung untuk mengetahui kemampuan sosial emosional anak kelompok B melalui media buku cerita kisah-kisah Nabi.

b. Tahap pelaksanaan tindakan

Pelaksanaan kegiatan belajar mengajar untuk siklus II dilaksanakan pada bulan Juni di RAM NU 10 Banin Banat Manyar Gresik dengan jumlah siswa 20. Dalam hal ini peneliti bertindak sebagai guru.

Siklus II merupakan pelaksanaan perbaikan melalui media buku cerita kisah-kisah Nabi, adapun proses belajar mengajar mengacu pada RPPH yang telah dipersiapkan dengan memperhatikan revisi pada siklus I sehingga kesalahan atau kekurangan pada siklus I tidak terulang pada siklus II ini. Pada akhir pembelajaran siswa diberi tes tulis dengan tujuan 
mengetahui tingkat keberhasilan siswa dalam pembelajaran yang telah dilakukan. Adapun data hasil penelitian pada siklus II adalah sebagai berikut:

\section{Tabel 9}

'Data hasil peningkatan Kemampuan Sosial Emosional Anak Kelompok B Melalui Media Buku Cerita Kisah-Kisah Nabi pada proses pembelajaran siklus II'

\begin{tabular}{|c|l|c|c|c|c|}
\hline \multirow{2}{*}{ No Nama Siswa } & \multicolumn{5}{|c|}{ Kriteria } \\
\cline { 3 - 6 } & & 4 & 3 & 2 & 1 \\
\hline 1 & Adrian Faiz Prasetya & & $\sqrt{ }$ & & \\
\hline 2 & Aida Haresti Zahra & & & & \\
\hline 3 & Amabel Damara Elyfia & $\sqrt{ }$ & & & \\
\hline 4 & Arumi Warnasita & $\sqrt{ }$ & & & \\
\hline 5 & Imam Ikhwanul Kirom & & $\sqrt{ }$ & & \\
\hline 6 & Jaka Maulana Firmansyah & & $\sqrt{ }$ & & \\
\hline 7 & Marizka Oktaviani & $\sqrt{ }$ & & & \\
\hline 8 & Miftahul Sofiya Hartanti & $\sqrt{ }$ & & & \\
\hline 9 & Muhammad Ainun Majid & & $\sqrt{ }$ & & \\
\hline 10 & Muhammad Ali Fahmi & & & $\sqrt{ }$ & \\
\hline 11 & Muhammad Fahri Listian & & & $\sqrt{ }$ & \\
\hline 12 & Muhammad Rendi & $\sqrt{ }$ & & & \\
\hline 13 & Muhammad Rohid & $\sqrt{ }$ & & & \\
\hline 14 & Muhammad Surya & $\sqrt{ }$ & & & \\
\hline 15 & Ni'am Zulkarnain & & $\sqrt{ }$ & & \\
\hline 16 & Reyhan Efendi & & $\sqrt{ }$ & & \\
\hline 17 & Risa Dafiyah Abidah & $\sqrt{ }$ & & & \\
\hline 18 & Vita Velysa Aura Salwa & $\sqrt{ }$ & & & \\
\hline 19 & Weny Winda Yanti & & & \\
\hline 20 & Zul Zeti Romatia & & & \\
\hline
\end{tabular}

Keterangan :

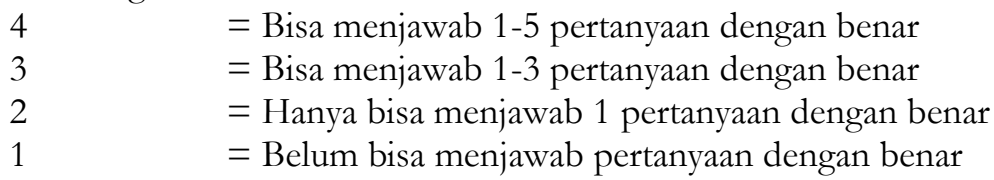

Berdasarkan hasil penelitian siklus II peningkatan kemampuan sosial emosional anak kelompok B melalui media buku cerita kisah-kisah Nabi yaitu 10 anak masuk kriteria sangat baik, 6 anak baik, dan 4 anak cukup baik. Hasil pada siklus II ini telah mengalami peningkatan lebih dari siklus I. Adanya peningkatan hasil belajar pada siklus II ini dipengaruhi oleh adanya peningkatan kemampuan sosial emosional anak kelompok B melalui media buku cerita kisahkisah Nabi, siswa lebih aktif dan siswa lebih senang belajar dengan media buku cerita kisahkisah Nabi karena menurut mereka belajar itu menyenangkan.

\section{Tabel 10}

'Data ketuntasan hasil belajar siswa Tentang peningkatan kemampuan sosial emosional anak kelompok B melalui media buku cerita kisah-kisah Nabi siklus II'

\begin{tabular}{|c|l|c|l|}
\hline No & \multicolumn{1}{|c|}{ Nama Siswa } & Bintang & \multicolumn{1}{c|}{ Kriteria } \\
\hline 1 & Adrian Faiz Prasetya & 3 & Berkembang sesuai harapan \\
\hline 2 & Aida Haresti Zahra & 3 & Berkembang sesuai harapan \\
\hline 3 & Amabel Damara Elyfia & 2 & Mulai berkembang \\
\hline 4 & Arumi Warnasita & 1 & Belum berkembang \\
\hline 5 & Imam Ikhwanul Kirom & 3 & Berkembang sesuai harapan \\
\hline 6 & Jaka Maulana Firmansyah & 2 & Mulai berkembang \\
\hline 7 & Marizka Oktaviani & 2 & Mulai berkembang \\
\hline 8 & Miftahul Sofiya Hartanti & 1 & Belum berkembang \\
\hline 9 & Muhammad Ainun Majid & 1 & Belum berkembang \\
\hline
\end{tabular}




\begin{tabular}{|l|l|c|l|}
\hline 10 & Muhammad Ali Fahmi & 1 & Belum berkembang \\
\hline 11 & Muhammad Fahri Listian & 2 & Mulai berkembang \\
\hline 12 & Muhammad Rendi & 3 & Berkembang sesuai harapan \\
\hline 13 & Muhammad Rohid & 1 & Belum berkembangl \\
\hline 14 & Muhammad Surya & 3 & Berkembang sesuaiharapan \\
\hline 15 & Ni'am Zulkarnain & 2 & Mulai berkembang \\
\hline 16 & Reyhan Efendi & 2 & Mulai berkembang \\
\hline 17 & Risa Dafiyah Abidah & 1 & Belum berkembang \\
\hline 18 & Vita Velysa Aura Salwa & 1 & Belum berkembang \\
\hline 19 & Weny Winda Yanti & 1 & Belum berkembang \\
\hline 20 & Zul Zeti Romatia & 2 & Mulai berkembang \\
\hline
\end{tabular}

Berdasarkan hasil belajar pada siklus II kemampuan sosial emosional anak kelompok B melalui media buku cerita kisah-kisah Nabi 4 anak mulai berkembang, 9 anak masuk kriteria berkembang sesuai harapan dan 7 anak berkembang sangat baik. Untuk itu pada siklus II tidak perlu di ulang lagi. Karena sudah ada peningkatan.

c. Tahap observasi

Tahap ini dilaksanakan bersamaan dengan pelaksanaan tindakan, dari hasil pengamatan yang dilakukan peneliti dan dibantu oleh teman sejawat maka diperoleh hasil sebagai berikut:

\section{Tabel 11}

'Pedoman observasi aktivitas belajar Tentang peningkatan kemampuan sosial emosional anak kelompok B melalui media buku cerita kisah-kisah Nabi siklus II'

\begin{tabular}{|c|l|c|}
\hline No & \multicolumn{1}{|c|}{ Aktivitas belajar siswa } & Kriteria \\
\hline 1 & Memperhatikan penjelasan guru & \\
\hline 2 & Siswa berperan aktif dalam pembelajaran & \\
\hline 3 & $\begin{array}{l}\text { Tanggap dengan media pembelajarn yang telah diterapkan oleh } \\
\text { guru }\end{array}$ & \\
\hline 4 & Berprilaku yang tidak sesuai selama KBM berlangsung & \\
\hline
\end{tabular}

Keterangan :

$1=$ Tidak positif

2 = Cukup positif

$3=$ Positif

4 = Sangat positif

\section{Tabel 12}

'Data aktivitas belajar siswa Tentang peningkatan kemampuan sosial emosional anak kelompok B melalui media buku cerita kisah-kisah Nabi siklus II'

\begin{tabular}{|c|l|c|}
\hline No & \multicolumn{1}{|c|}{ Nama Siswa } & Kriteria \\
\hline 1 & Ahmad Maulana Haqiqi & 4 \\
\hline 2 & Akhmad Raza Natagara & 4 \\
\hline 3 & Bela Kurniawati & 3 \\
\hline 4 & Dhea Shafiratuz Zahroh & 4 \\
\hline 5 & Faizatin Nisa' & 3 \\
\hline 6 & Friska Cecilia & 3 \\
\hline 7 & Habibatul Azifah & 2 \\
\hline 8 & Muhammad Asrori & 3 \\
\hline 9 & Muhammad Azam Ubaidillah & 2 \\
\hline 10 & Muhammad Fakhry Ali Rabbani & 3 \\
\hline 11 & Muhammad Fakry Listian & 4 \\
\hline 12 & Muhammad Fatkhur Nur Rohman & 3 \\
\hline 13 & Muhammad Refan Hibatullah & 4 \\
\hline 14 & Tsania Alifatur Rahmah & 3 \\
\hline 15 & Ni'am Zulkarnain & 2 \\
\hline 16 & Reyhan Efendi & \\
\hline
\end{tabular}




\begin{tabular}{|l|l|l|}
\hline 17 & Risa Dafiyah Abidah & 3 \\
\hline 18 & Vita Velysa Aura Salwa & 4 \\
\hline 19 & Weny Winda Yanti & 3 \\
\hline 20 & Zul Zeti Romatia & 4 \\
\hline
\end{tabular}

Menurut data diatas bahwa secara garis besar aktivitas siswa yaitu dalam kriteria cukup positif 3 anak, positif 7 anak dan sangat positif 10 anak. Menurut data diatas bahwa secara garis besar aktifitas siswa mengalami peningkatan.

\section{Tabel 13}

'Data aktivitas guru yang dinilai teman sejawat Tentang peningkatan kemampuan sosial emosional anak kelompok B melalui media buku cerita kisah-kisah Nabi siklus II'

\begin{tabular}{|c|l|c|}
\hline No & \multicolumn{1}{|c|}{ Aktivitas guru } & Skor \\
\hline 1 & Melakukan apersepsi & 4 \\
\hline 2 & Memotivasi siswa & 4 \\
\hline 3 & $\begin{array}{l}\text { Membimbing siswa dalam meningkatkan kemampuan sosial } \\
\text { emosional anak kelompok B melalui media buku cerita kisah-kisah } \\
\text { Nabi }\end{array}$ & 4 \\
\hline 4 & Menggunakan media dan sumber yang beragam & 4 \\
\hline 5 & $\begin{array}{l}\text { Memberikan tantangan kepada siswa dengan memberikan } \\
\text { penghargaan }\end{array}$ & 3 \\
\hline 6 & Menguasai kelas & 3 \\
\hline 7 & Proses pembelajaran sesuai RPPH & 4 \\
\hline 8 & Alokasi waktu sesuai dengan yang diterapkan & 4 \\
\hline
\end{tabular}

Keterangan nilai skor:

1 = Kurang baik3 = Baik

$2=$ Cukup baik $4=$ Baik sekali

Menurut data diatas bahwa secara garis besar aktivitas guru rata-rata 4 yaitu dalam kategori baik sekali. Guru sudah bisa memperbaiki kekurangan pada pelaksanaan siklus I.

d. Refleksi

Tahap ini akan dikaji apa yang telah terlaksana dengan baik maupun yang masih kurang dalam proses peningkatan kemampuan sosial emosional anak kelompok B melalui media buku cerita kisah-kisah Nabi dari data-data yang diperoleh dapat diuraikan sebagai berikut:

1) Selama proses mengajar guru telah melaksanakan semua pembelajaran dengan baik. Meskipun ada beberapa aspek yang belum sempurna, tetapi persentase pelaksanaannya masing-masing cukup besar.

2) Siswa aktif selama proses belajar berlangsung.

3) Kekurangan pada siklus-siklus sebelumnya sudah mengalami perbaikan dan peningkatan sehingga menjadi lebih baik.

4) Hasil belajar siswa pada siklus II ini mencapai peningkatan.

e. Revisi

Pada siklus II ini guru telah menerapkan pembelajaran pada aspek peningkatan kemampuan sosial emosional anak kelompok B melalui media buku cerita kisah-kisah Nabi dengan baik dan dilihat dari aktifitas siswa serta hasil belajar siswa, pelaksanaan proses pembelajaran sudah berjalan dengan baik, maka tidak diperlukan revisi terlalu banyak, tetapi perlu diperhatikan untuk tindakan selanjutnya adalah memaksimalkan dan mempertahankan apa yang telah ada dengan tujuan pembelajaran dapat tercapai. 


\section{Analisis kuantitatif deskritif}

Dalam analisis data dan pembahasan ini agar lebih mudah dipahami oleh pembaca. Data yang penulis sajikan berdasarkan hasil penskoran anak kelompok B dan angket dan interview dengan guru di RAM NU 10 Banin Banat Manyar Gresik dengan menggunakan rumus sebagai berikut :

$$
\mathrm{P}=\frac{\mathrm{F}}{\mathrm{N}} \times 100 \%
$$

Keterangan :

$\mathrm{P} \quad=$ Populasi

$\mathrm{F} \quad=$ Frekuensi Jawaban Responden

$\mathrm{N} \quad=$ Jumlah Responden

$100 \%=$ Bilangan Standarisasi

Sesuai dengan masalah dan tujuan yang penulis rumuskan, maka dalam penyajian analisa data ini penulis mengklasifikasikan menjadi dua bagian, yaitu :

a. Poin 1 - 5 tentang kemampuan sosial emosional anak kelompok B di RAM 10 Manyar Gresik.

b. Poin $6-10$ tentang upaya meningkatkan kemampuan sosial emosional anak kelompok B melalui media buku cerita kisah-kisah Nabi di RAM 10 Manyar Gresik.

Adapun data yang diperoleh dari penyebaran angket ini masing-masing diberi 3 alternatif jawaban, kemudian dinilai dengan cara menjumlah dari setiap jawaban orang tua. Sebagai standart penulis tetapkan sebagai berikut :

a. Alternatif "a" diberi skor 3 dengan kategori baik

b. Alternatif "b" diberi skor 3dengan kategori cukup

c. Alternatif "c" diberi skor 3dengan kategori kurang

Selanjutnya untuk mendapatkan gambaran yang lebih jelas mengenai hasil penelitian yang terkumpul, maka dapat dilihat pada bagian berikut yang disajikan dengan menggunakan tabeltabel beserta analisanya :

Tabel 14

'Data kemampuan sosial emosional anak kelompok B melalui media buku cerita kisah-kisah nabi'

\begin{tabular}{|c|c|c|c|c|c|c|c|c|}
\hline \multirow{2}{*}{ No } & \multirow{2}{*}{ Uraian } & \multicolumn{2}{|r|}{ A } & \multicolumn{2}{|r|}{ B } & \multicolumn{2}{|r|}{$\mathrm{C}$} & Jml \\
\hline & & & $\%$ & & $\%$ & & $\%$ & $\mathrm{~N} \%$ \\
\hline 1 & Memperhatikan penjelasan guru & 14 & 70 & 4 & 20 & 2 & 10 & $20 \quad 100$ \\
\hline 2 & $\begin{array}{l}\text { Anak berperan aktif dalam } \\
\text { pembelajaran }\end{array}$ & 16 & 80 & 3 & 15 & 1 & 5 & 20100 \\
\hline 3 & $\begin{array}{l}\text { Tanggap dengan media pembelajarn } \\
\text { yang telah diterapkan oleh guru }\end{array}$ & 17 & 85 & 3 & 15 & - & - & 20100 \\
\hline 4 & $\begin{array}{l}\text { Berprilaku yang tidak sesuai selama } \\
\text { KBM berlangsung }\end{array}$ & 16 & 80 & 2 & 10 & 2 & 10 & 20100 \\
\hline 5 & $\begin{array}{l}\text { Selalu mengikuti kegiatan-kegiatan di } \\
\text { sekolah }\end{array}$ & 17 & 85 & 2 & 10 & 1 & 5 & 20100 \\
\hline
\end{tabular}

Dalam tabel di atas terdapat lima item pertanyaan pertama tentang memperhatikan penjelasan guru, kebanyakan anak memperhatikan penjelasan guru, terbukti $70 \%$ menjawab a, 20\% menjawab b, dan 10\% menjawab c. Kedua tentang Anak berperan aktif dalam pembelajaran sebanyak $80 \%, 15 \%$ menjawab b, dan 5\% menjawab c. Ketiga tentang Tanggap dengan media pembelajaran yang telah diterapkan oleh guru sebanyak $85 \%, 15 \%$ menjawab b, yang menjawab item c tidak ada. Keempat tentang Berprilaku yang tidak sesuai selama KBM berlangsung sebanyak 80\%, 10\% menjawab b, dan 10\% menjawab c. Kelima tentang Selalu mengikuti kegiatan-kegiatan di sekolah sebanyak 85\%,10\% menjawab b, 5\% menjawab c.

Untuk menganalisa data tentang upaya meningkatkan kemampuan sosial emosional anak kelompok B melalui media buku cerita kisah-kisah Nabi di RAM 10 Manyar Gresik, penulis menggunakan analisa data statistik sederhana yaitu prosentase. 
Untuk menafsirkan hasil perhitungan dengan prosentase tersebut, penulis menetapkan standart sebagai berikut :

a. $76 \%-100 \%$ tergolong baik

b. $56 \%-75 \%$ tergolong cukup

c. $40 \%-55 \%$ tergolong kurang

d. Kurang dari $40 \%$ tergolong tidak baik

Dari perhitungan data pada tabel 4.4 berisikan point $1-5$ diketahui jumlah prosentasinya antara lain $70 \%, 80 \%, 85 \%, 80 \%, 85 \%$, kemudian dari jumlah tersebut dibagi dengan jumlah item sebanyak 5 , maka rata-rata nilainya adalah sebagai berikut:

$$
\frac{70 \%+80 \%+85 \%+80 \%+85 \%}{55}=\underline{400 \%}=80 \%
$$

Berdasarkan pada standart yang penulis tetapkan sebelumnya, maka nilai $80 \%$ tergolong baik, karena berada diantara 76\%-100\%. Sehingga dari perhitungan ini dapat diketahui bahwa upaya meningkatkan kemampuan sosial emosional anak kelompok B melalui media buku cerita kisahkisah Nabi di RAM 10 Manyar Gresik tergolong baik.

\section{Kesimpulan}

Berdasarkan hasil penelitian dan pembahasan, dapat diambil kesimpulan sebagai berikut:

1. Upaya meningkatkan kemampuan sosial emosional anak kelompok $B$ melalui media buku cerita kisah-kisah Nabi di RAM 10 Manyar Gresik tergolong baik. Hal ini dapat dibuktikan dengan nilai 80\% tergolong baik, karena berada diantara 76\% - 100\% yang berarti baik.

2. Kemampuan sosial emosional anak kelompok B di RAM NU 10 Banin Banat Manyar Gresik tergolong baik. Hal ini dapat dibuktikan ketika anak memasuki sekolah mereka selalu mengikuti pelajaran, mendengarkan guru, dan mematuhi tata tertib sekolah.

3. Media buku cerita kisah-kisah Nabi dapat meningkatkan kemampuan sosial emosional anak Kelompok B di RAM NU 10 Banin Banat Manyar Gresik. Hal ini dapat dibuktikan dengan meningkatnya kemampuan sosial emosional anak Kelompok B dalam media buku cerita kisahkisah Nabi. Kondisi pada Pra tindakan masih kurang baik, kemudian pada Siklus I kemampuan sosial emosional anak Kelompok B dalam media buku cerita kisah-kisah Nabi menjadi baik, pada Siklus II kemampuan sosial emosional anak Kelompok B dalam media buku cerita kisah-kisah Nabi meningkat sangat baik. 


\section{Daftar Pustaka}

Anas Sudijono. Pengantar Evaluasi Pendidikan. Jakarta: Rajawali Pers, 2011.

Anwar Sanusi. Metode Penelitian Bisnis. Jakarta: Salemba Empat, 2011.

Ari Ginanjar Agustian. (2003). ESQ Power. Jakarta : PT. Arga.

Burhan Bungin. (2000). Metodologi Penelitian. Surabaya : Airlangga University Press.

Deni Mahardika. Menerapkan Hypnostudying. Yogyakarta: Diva Press, 2015.

Djam'an Satori, Aan Komariah. Metodologi Penelitian Kualitatif. Bandung: Alfabeta, 2014.

Ega Rima Wati \& Shinta Kusuma. Menjadi Guru Hebat dengan Hypnoteaching. Yogyakarta: Kata Pena, 2016.

Endang Mulyatiningsih. Metode Penelitian Terapan Bidang Pendidikan. Bandung: Alfabeta, 2014.

Faridatul Aini. - Pengaruh Metode Pembelajaran Hypnoteaching terhadap Peningkatan Kemampuan Berpikir Kreatif Matematis dan Anxiety Peserta Didikll. (Skripsi pada IAIN Raden Intan Lampung), 2014.

Hani Handayani. -Pengaruh Pembelajaran Kontekstual Terhadap Kemampuan Pemahaman dan Representasi Matematis Siswa Sekolah Dasarll. (Tesis pada Pascasarjana UPI Bandung), 2013.

Hendri Sujatmiko. "Konsep Hypnoteaching Menurut Buku Hypnoteaching for Succes Learning Karya Mohammad Noer dan Relevansinya dengan Pembelajaran PAI. (Skripsi pada UIN Sunan Kalijaga Yogyakarta), 2012.

Lexy J. Moleang. (1994). Metode Penelitian Kualitatif. Bandung : PT. Remaja Rosda Karya.

Mahfud, Sholahuddin,Drs. (1987). Metodologi Pendidikan Agama. Surabaya : PT. Bina Ilmu.

Ngalim Purwanto. (2004). Psikologi Pendidikan. Bandung : PT. Remaja Rosdakarya.

Riduan, M.B.A. (2005). Belajar Mudah Penelitian untuk Guru, Karyawan dan Peneliti Pemula. Bandung : PT. Alfabeta.

Saifuddin Azwar. (1999). Metodologi Penelitian Suatu Pendekatan Praktek. Jakarta : PT. Rineka Cipta.

Suharsimi Arikunto. (1992). Prosedur Penelitian Suatu Pendekatan Praktek. Jakarta : PT. Rineka Cipta.

Sutrisno Hadi. (1983). Metodologi Riset I. Yogyakarta : Andy Offset.

Taufiq Pasiak. (2005). Revolusi IQ/EQ/SQ. Yogyakarta : PT. Mizan Pustaka.

Winarno Surachmad. (1990). Pengantar Penelitian Ilmiah. Bandung : CV. Tarsito.

Wiriatmadja, Rochiati. (2006). Metode Penelitian Tindakan Kelas. Bandung : PT. Remaja Rosdakarya. 